\title{
Dielectric Behavior and Morphostructural Characteristics of Some HDPE Composites / Metal Nanopowders
}

\author{
ALINA-RUXANDRA CARAMITU ${ }^{1}$, SORINA MITREA ${ }^{1}$, VIRGIL MARINESCUㄴ, GEORGE-ANDREI URSAN ${ }^{2}$, MIHAELA ARADOAIE ${ }^{3}$, \\ IOSIF LINGVAY** \\ ${ }^{1}$ National Institute for Research and Development in Electrical Engineering INCDIE ICPE-CA, 313, Splaiul Unirii, 030138, Bucharest, \\ Romania \\ 2.Technical University Gh. Asachi lasi 53A, Dimitrie Mangeron Blvd., 700050, Iasi, Romania \\ 3.ALL GREEN SRL lasi 8, George Cosbuc Blvd., 700470, lasi, Romania
}

\begin{abstract}
HDPE composite samples with aluminum and iron nanopowders were made by extrusion and injection. Samples of material obtained were characterized by comparative determinations of dielectric spectroscopy and SEM microscopy. SEM images have indicated that the agglomerations of the powders used are persistent, do not decompose during extrusion and injection processing. Determinations by dielectric spectroscopy indicated that HDPE composite materials with metal nanopowder filler have higher dielectric losses than pure HDPE (reference). The highest increases in tg $\delta$ up to 2.6 times, were recorded for $50 \mathrm{~nm}$ nanopowders with specific high surface area (over $20 \mathrm{~m}^{2} / \mathrm{g}$ ). The electrical conductivity of the investigated samples increases with increasing frequency, both for pure HDPE and for HDPE with metal powder filler. As a result of the film effect in the HDPE case with metal filler, the increases in the high frequencies range are lower than in the extremely low frequencies range.
\end{abstract}

Keywords: HDPE, iron nanopowder, aluminum nanopowder, composite, dielectric loss, conductivity

The advanced materials development for various industrial applications is a priority issue in the concept of sustainable development perspective.

In this context, in developing and classifying materials, besides application-specific functional characteristics, it is intended that both the production methods $[1,2]$ and the end-of-life [3 - 11] waste treatment technologies to be environmentally friendly [12], respectively the material specific energy and consumptions as low as possible, as well as not to involve persistent noxious dispersions [1324], readily biodegradable / remineralizable [25-30] etc.

Polymer-based composites with various fillers (wood, silicate, clay, metal, carbon, etc.) have electrical, mechanical and functional characteristics [31-42] that recommend their use in the most diverse applications. The composite polymer / filler materials characteristics are largely determined both by the structure and nature of the filler and by the constituents blending and the composites obtaining [43], respectively.

In view of these considerations, the paper aim consists in characterization the morphostructural and dielectric of some high-density polyethylene (HDPE) based composites, with fillers metal nanopowders for use in various applications such as semiconductor and / or shielding polymeric layers electromagnetic.

\section{Experimental part}

HDPE composites samples/ metal nanopowder were prepared by extrusion. Samples were obtained in two stages.

In the first step, the components (HDPE and metallic powder) were blended and by extrusion (on a Brabender KETSE type laboratory extruder) the composite granules were obtained. In the second step, the composite granules were injected (with a Dr. Boy A35-Germany type injection machine), thus samples disk shaped are obtained with a diameter of $30 \mathrm{~mm}$ and a thickness of $2.5 \mathrm{~mm}$.
The working parameters on the extruder were:

- extruder screw speeds of $45 \mathrm{rpm}$;

- power funnel screw speed: 700 rpm;

- the temperatures on the heating zones of the extruder are shown in table 1.

Table 1

TEMPERATURES ON THE EXTRUDER HEATING AREAS

\begin{tabular}{|c|c|c|c|c|c|c|}
\hline Area & 1 & 2 & 3 & 4 & 5 & 6 \\
\hline Temperature $\left[{ }^{\circ} \mathrm{C}\right]$ & 165 & 170 & 175 & 180 & 185 & 190 \\
\hline
\end{tabular}

The working parameters on the injection machine were: -the matrices closing force in $302-317 \mathrm{kN}$ range -the injection pressure: 550 barr

-the counter pressure: 90 barr

-the injection matrices temperature: $15-20^{\circ} \mathrm{C}$

-the injection machine heating area temperatures were shown in table 2.

Table 2

TEMPERATURES ON THE INJ ECTION MACHINE HEATING AREAS

\begin{tabular}{|c|c|c|c|c|c|}
\hline Area & 5 & 4 & 3 & 2 & 1 \\
\hline Temperature $\left[{ }^{\circ} \mathrm{C}\right]$ & 190 & 180 & 175 & 170 & 165 \\
\hline
\end{tabular}

In order to determine the optimal temperature, range for processing on extruder and injection machine, the DSC technique was used (with a 131 EVo Setaram type equipment).

Thus, the melting temperature and start temperature of the first thermooxidation process of the HDPE granules used were determined. Determinations were made on synthetic air samples of $50 \mathrm{~mL} /$ minute at a heating speed of $10^{\circ} \mathrm{C} / \mathrm{min}$. Composite samples were prepared with HDPE granules Tipelin 1100 J type with the properties shown in table 3 [44].

The metal powders used were purchased from NANOGRAFI LTD.STI, Ankara Turkey and have the following characteristics [45]:

*email: iosiflingvay@yahoo.com;, Phone: +40744680238 


\begin{tabular}{|l|c|c|}
\hline \multicolumn{1}{|c|}{ Properties/Standard } & Unit & Value \\
\hline MFR (190 $\left.{ }^{\circ} \mathrm{C} / 2.16 \mathrm{~kg}\right):$ ISO 1133-1 & $\mathrm{g} / 10 \mathrm{~min}$ & 8.0 \\
\hline Density (230C): ISO 1183-2 & $\mathrm{Kg} / \mathrm{m}^{3}$ & 961 \\
\hline Traction resistance: ISO 527-3 & $\mathrm{MPa}$ & 12 \\
\hline Elongation at break: ISO 527-3 & $\%$ & 580 \\
\hline Young module: ISO 178 & $\mathrm{MPa}$ & 1500 \\
\hline Izod impact resistance: ISO 180/A & $\mathrm{kJ} / \mathrm{m}^{2}$ & 5 \\
\hline Shore D Hardness: ISO 868 & - & 63 \\
\hline Scraping resistance (TD /MD): ISO 294-4 & $\%$ & $2.1 / 2.0$ \\
\hline
\end{tabular}

Table 3

HDPE GRANULES CHARACTERISTICS
a)Aluminium Nanopowder with $99.995 \%$ purity, $800 \mathrm{~nm}$ particle size

\begin{tabular}{|l|c|}
\hline Shape: & spherical \\
\hline Crystal Structure: & cubic \\
\hline Average Particle Size [nm]: & 800 \\
\hline Specific Surface Area [m² $/ \mathrm{g}]:$ & $15-20$ \\
\hline
\end{tabular}
size

b) Iron Nanopow der with $99.995 \%$ purity $790 \mathrm{~nm}$ particle

\begin{tabular}{|l|c|}
\hline True Density $\left[\mathrm{g} / \mathrm{cm}^{3}\right]:$ & 7.9 \\
\hline Color: & dark grey \\
\hline Crystal Structure: & cubic \\
\hline$\Gamma_{\text {melting }}\left[{ }^{\circ} \mathrm{C}\right]:$ & 1538 \\
\hline$\left.\Gamma_{\text {boiling }}{ }^{\circ} \mathrm{C}\right]:$ & 2862 \\
\hline Average Particle Size [nm]: & 790 \\
\hline Specific Surface Area $\left[\mathrm{m}^{2} / \mathrm{g}\right]:$ & $5-10$ \\
\hline
\end{tabular}

c) Aluminium nanopowder with $99.995 \%$ purity $50 \mathrm{~nm}$ particle size

\begin{tabular}{|l|c|}
\hline Bulk Density $\left[\mathrm{g} / \mathrm{cm}^{3}\right]:$ & 0.22 \\
\hline True Density $\left[\mathrm{g} / \mathrm{cm}^{3}\right]:$ & 2.7 \\
\hline Shape: & spherical \\
\hline Crystal Structure: & cubic \\
\hline Average Particle Size [nm]: & 50 \\
\hline Specific Surface Area [m $2 / \mathrm{g}]:$ & $20-30$ \\
\hline
\end{tabular}

d) Iron Nanopowder with $99.995 \%$ purity $50 \mathrm{~nm}$ particle size

\begin{tabular}{|l|c|}
\hline Bulk Density $\left[\mathrm{g} / \mathrm{cm}^{3}\right]$ : & 0.5 \\
\hline True Density $\left[\mathrm{g} / \mathrm{cm}^{3}\right]:$ & 7.9 \\
\hline Color: & black \\
\hline Crystal Structure: & cubic \\
\hline Average Particle Size [nm]: & $40-50$ \\
\hline Specific Surface Area [m $/ \mathrm{g}]:$ & $10.0-15.0$ \\
\hline
\end{tabular}

The nanopowders morphostructure used and the composites obtained were evaluated by SEM technique with a type INCA Energy 250 energy dispersive spectrometer (EDS) - Oxford Instruments belonging Auriga (Zeiss) field emission scanning electron microscope (FESEM) equipment. The powders granulometric distribution used was determined by processing with the image/ software of the SEM images obtained.

Dielectric behaviour of composite samples was investigated at $20 \pm 2{ }^{\circ} \mathrm{C}$ by dielectric spectroscopy technique with 1296 Dielectric interface / AMTEK - Solartron Analytical.

\begin{tabular}{|c|c|c|}
\hline Sample code & Composition & \\
\hline M1 & pure HDPE (reference) & \\
\hline $\mathrm{M} 2$ & $\mathrm{HDPE}+3 \%$ Al $800 \mathrm{~nm}$ & \\
\hline$\overline{\mathrm{M} 3}$ & $\mathrm{HDPE}+5 \%$ Al $800 \mathrm{~nm}$ & \\
\hline M4 & $\mathrm{HDPE}+8 \%$ Al $800 \mathrm{~nm}$ & \\
\hline$\overline{M 5}$ & $\mathrm{HDPE}+3 \% \mathrm{Al} 50 \mathrm{~nm}$ & \\
\hline M6 & $\mathrm{HDPE}+5 \%$ AI $50 \mathrm{~nm}$ & Table 4 \\
\hline M7 & $\mathrm{HDPE}+8 \% \mathrm{Al} 50 \mathrm{~nm}$ & SAMPLESOF \\
\hline M8 & HDPE $+3 \% \mathrm{Fe} 790 \mathrm{~nm}$ & COMPOSITE PREPARED \\
\hline M9 & HDPE $+5 \% \mathrm{Fe} 790 \mathrm{~nm}$ & \\
\hline M10 & $\mathrm{HDPE}+8 \% \mathrm{Fe} 790 \mathrm{~nm}$ & \\
\hline M11 & $\mathrm{HDPE}+3 \% \mathrm{Fe} 50 \mathrm{~nm}$ & \\
\hline M12 & $\mathrm{HDPE}+5 \% \mathrm{Fe} 50 \mathrm{~nm}$ & \\
\hline M13 & $\mathrm{HDPE}+8 \% \mathrm{Fe} 50 \mathrm{~nm}$ & \\
\hline
\end{tabular}

The content in metal nanopowders and samples code is shown in table 4.

\section{Results and discussions}

The DSC diagram obtained on the HDPE granules used for sample preparation is shown in figure 1 .

Analyzing the DSC curve in figure 1 it is noticed that at progressive heating of the material at $133.47^{\circ} \mathrm{C}$ shows an endothermic peak corresponding to the melting process ending at $149.11{ }^{\circ} \mathrm{C}$. Upon continued heating at $230.15^{\circ} \mathrm{C}$, it begins the first thermooxidation endothermic process of polymer which takes place at a maximum speed of 243.55 ${ }^{\circ} \mathrm{C}$.

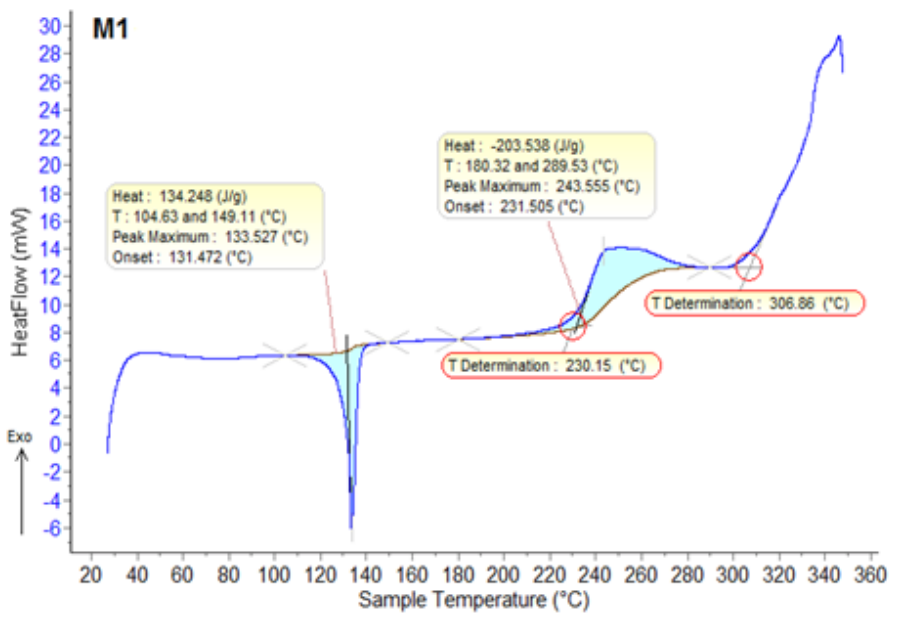

Fig. 1. DSC diagram of HDPE used

The range relatively low of temperatures at which takes place melting, as well as the process energy $(134.25 \mathrm{~J} / \mathrm{g})$ indicates a relatively high degree of ordering (crystallinity) of the polymer. These data and the start temperature of the first thermooxidation process $\left(230.15^{\circ} \mathrm{C}\right)$, indicate that high crystallinity is due to a relatively high degree of polymer crosslinking (large weight of tertiary and quaternary carbon atoms) [46-48].

Based on these results, the processing zone temperatures were determined for both extrusion (table 1) and injection (table 2) so that in each area the temperature was above the melting temperature, but below the first starting temperature of the thermooxidation process.

SEM assessments results of the metal powders used are shown in figures 2 - 5 .

Analyzing the SEM images in figures $2-5$, it is noted that the powders of Al $50 \mathrm{~nm}$ (fig. 2) have a cavernous morphology (which explains a relatively large specific surface area of $20-30 \mathrm{~m}^{2} / \mathrm{g}$ ) unlike the other powders (figs. 3 - 5) which have a spherical shape.

In figures 3-5 shows a tendency of particle agglomeration and a relatively large dispersion of diameters.

In view of these observations, digital image analysis of SEM images and plotting particle distribution histograms using the imagel software were performed. 


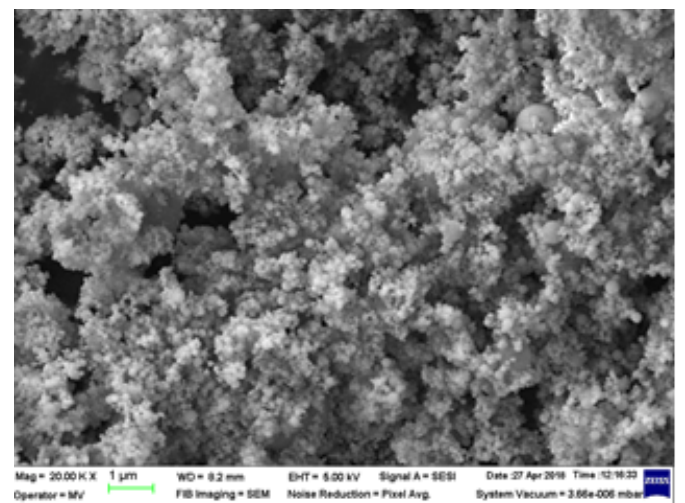

Fig. 2. SEM image of Al $50 \mathrm{~nm}$ powder

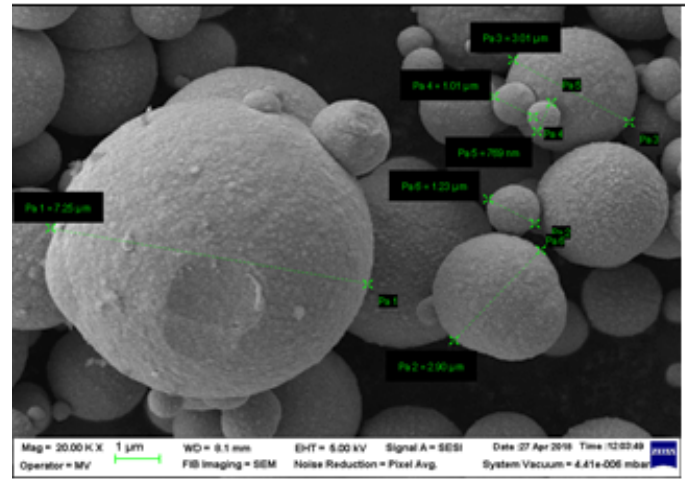

Fig. 4. SEM image of Fe $790 \mathrm{~nm}$ powder

The results obtained by processing the data provided by imageJ are shown in figures 6 - 9 .

Analyzing figures $6-9$ it is found that the histograms obtained are in accordance to the SEM images of figures 2 - 5, but present significant deviations from the supplier's technical specification [45].

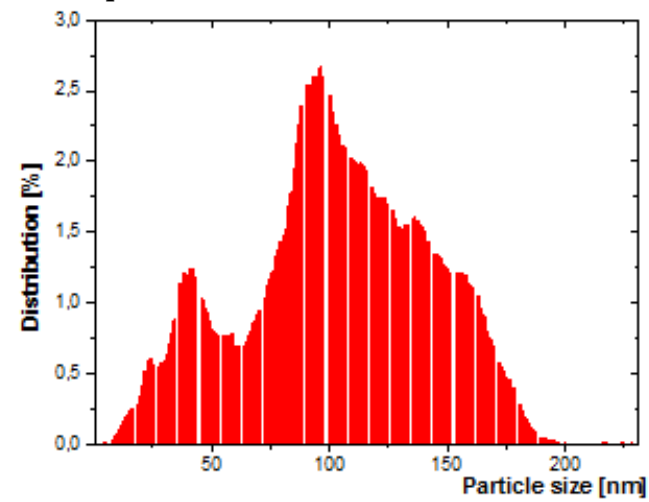

Fig. 6. Histogram -Ggranulometric distribution of Al $50 \mathrm{~nm}$ powder

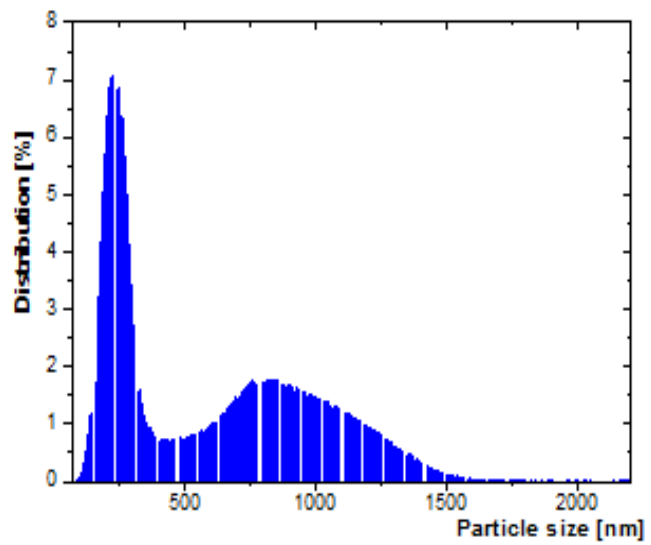

Fig. 7. Histogram -Granulometric distribution of Al $800 \mathrm{~nm}$ powder

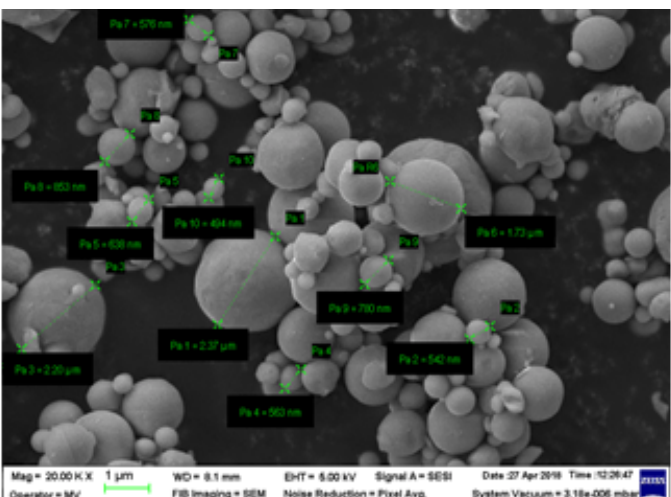

Fig. 3. SEM image of Al $800 \mathrm{~nm}$ powder

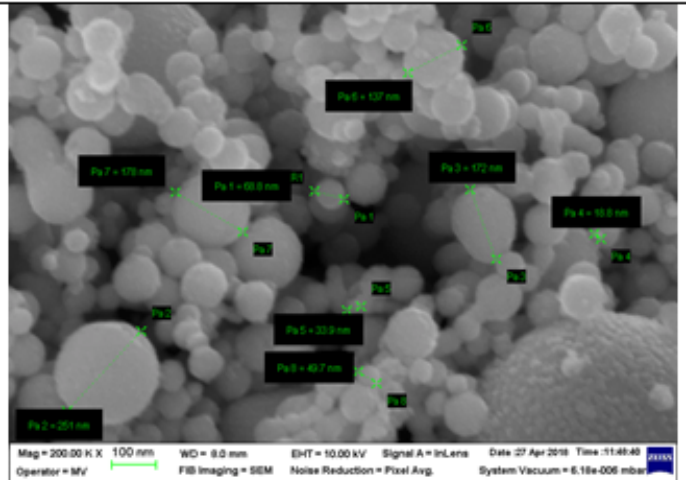

Fig. 5. SEM image of Fe $50 \mathrm{~nm}$ powder

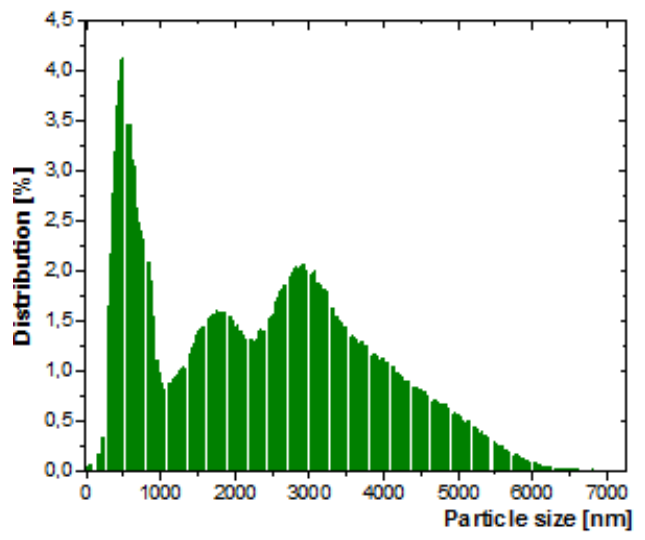

Fig. 8. Histogram -Granulometric distribution of Fe $790 \mathrm{~nm}$ powder

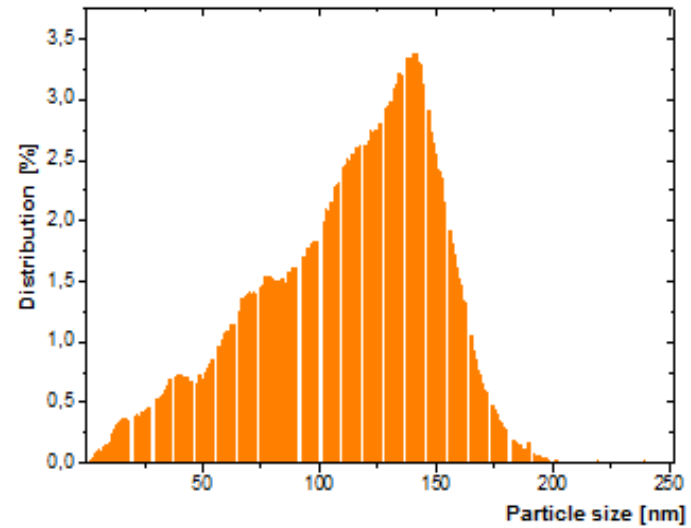

Fig. 9 Histogram -Granulometric distribution of Fe $50 \mathrm{~nm}$ powder

In figures 10-13 show the representative SEM images of the injected samples.

Analyzing figure 10 it is observed that the pure HDPE morphostructure injected is homogeneous. In figures 11 13 it is observed that in the HDPE composites, the metal powders are distributed relatively uniformly.

It is also observed that during extrusion and injection the dust agglomerations (visible in figs. 2-5) do not 


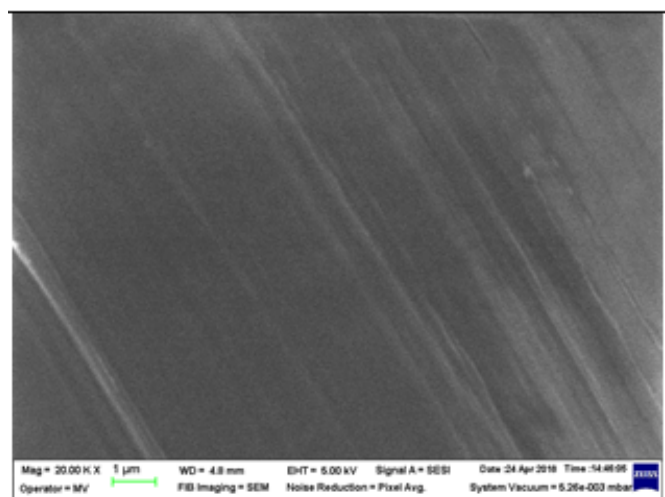

Fig. 10. SEM image of the M1 blank sample - pure HDPE

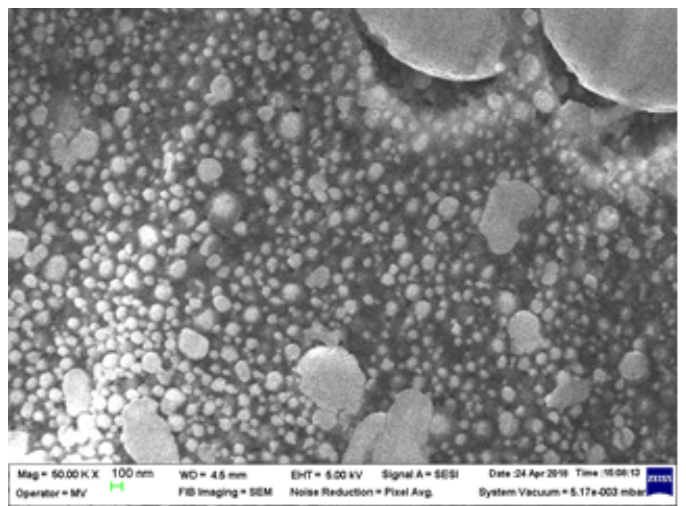

Fig. 12. SEM image of sample M7 (composite with $8 \% \mathrm{Al} 50 \mathrm{~nm}$ )

disintegrate - they are found entirely in the composite. Dielectric spectroscopy determinations in the investigated field $1 \mathrm{~Hz}-100 \mathrm{kHz}$ indicated that the dielectric losses $\operatorname{tg} \delta$ decrease continuously and monotonously.

Figures 14-16 show details about the dielectric losses evolution of the achieve composites (compared to the blank sample - HDPE pure) in the extremely low frequencies range $(5-50 \mathrm{~Hz})$ and in the high frequencies range $(6-10 \mathrm{kHz})$.

Analyzing figure 14a it is found that HDPE composites with 3\% metallic powder systematically investigated have dielectric losses (in the $5-50 \mathrm{~Hz}$ frequency range) by 1.7 to 2.3 times higher than the pure HDPE reference composite. The highest increases (about 2.3 times) were recorded for the Fe $50 \mathrm{~nm}$ powder and the smallest (about 1.7 times) for the Al $800 \mathrm{~nm}$ powder.

The $\operatorname{tg} \delta$ increases for $3 \%$ Al $50 \mathrm{~nm}$ powder and Fe 790 $\mathrm{nm}$ are approximately equal. Figure $14 \mathrm{~b}$ shown that the

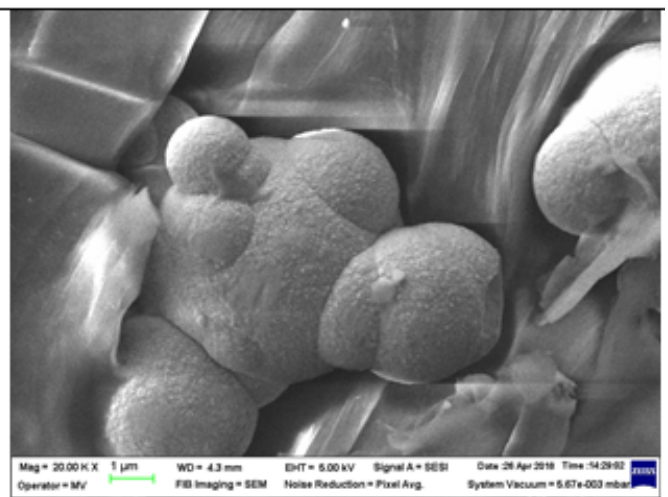

Fig. 11. SEM image of sample M10 (composite with $8 \%$ Fe $790 \mathrm{~nm}$ )

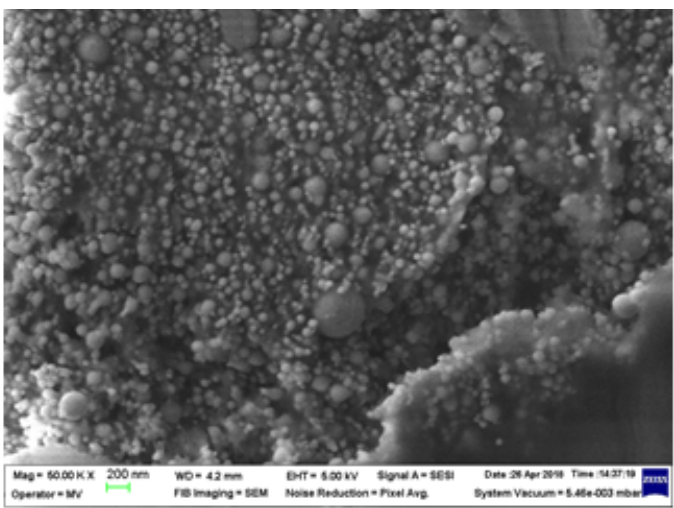

Fig. 13. SEM image of sample M13 (composite with 8

$\%$ Fe $50 \mathrm{~nm}$ )

trend of $\operatorname{tg} \delta$ evolution in the high frequencies domain is similar to that of extremely low frequencies.

Analyzing figure 15a it is found that HDPE composites with $5 \%$ metallic powder systematically investigated have dielectric losses (in the $5-50 \mathrm{~Hz}$ frequency range) by 1.8 to 2.6 times higher than the pure HDPE reference composite. The highest increases (about 2.6 times) were recorded for the Al $50 \mathrm{~nm}$ powder and the smallest (about 1.8 times) for the Al $800 \mathrm{~nm}$ powder. Figure $14 \mathrm{~b}$ ) shown that the trend of $g \delta$ evolution in the high frequencies domain is similar to that of extremely low frequencies, with the observation that $\operatorname{tg} \delta$ increases following the addition of dusts are systematically lower than in the $5-50 \mathrm{~Hz}$ frequency range.

Analyzing figure 16 it is noted that - both in the extremely low frequencies and in the high frequencies range - for the HDPE composites with $8 \%$ metallic pow der investigated, a

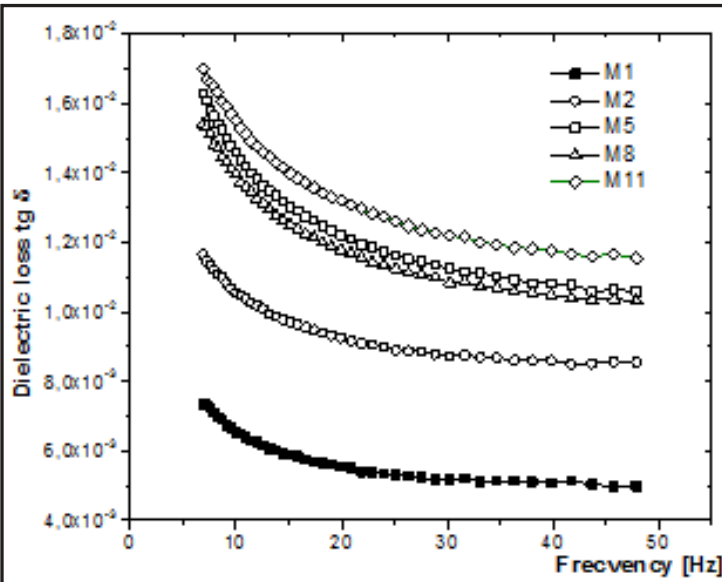

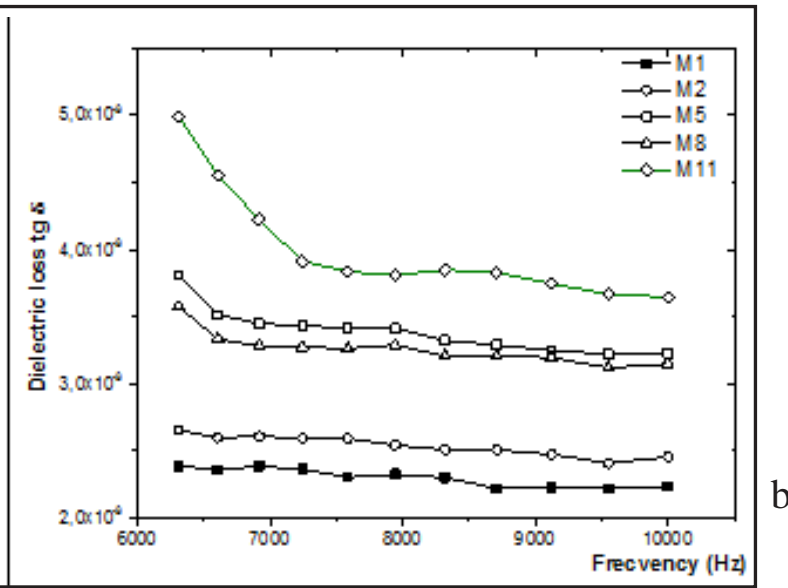

Fig. 14. Comparative evolutions of $\operatorname{tg} \delta$ in extremely low frequencies a) and at high frequencies $b$ ) of the composites with addition of $3 \%$ metallic powder 


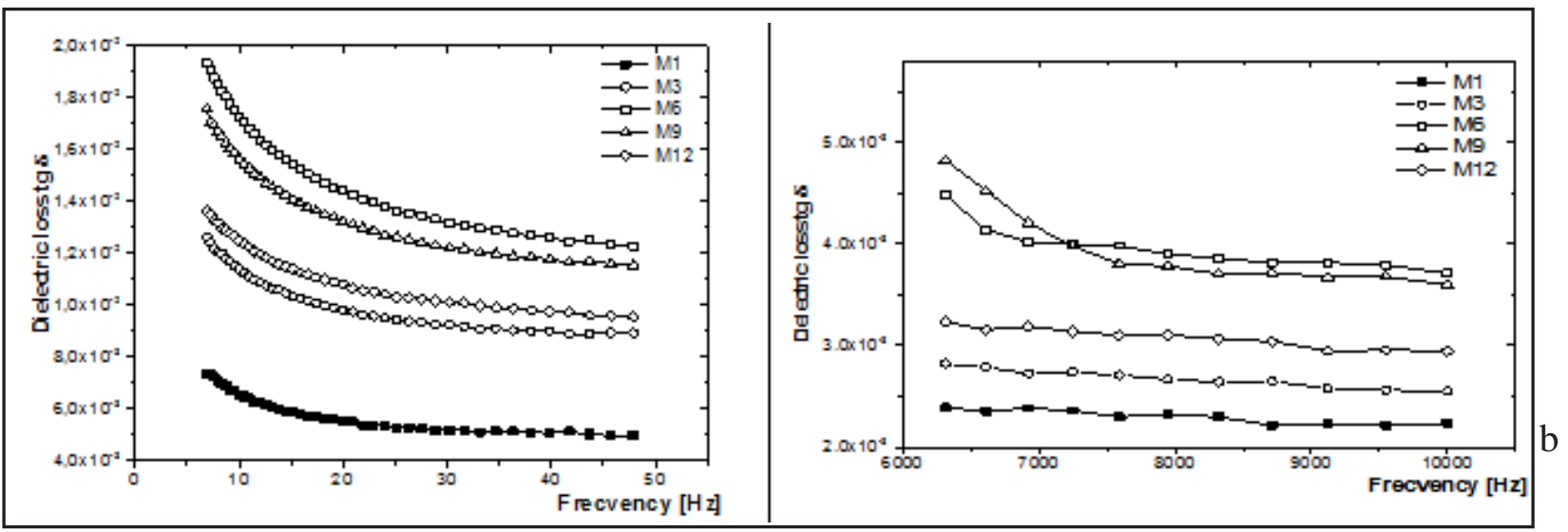

Fig. 15. Comparative evolutions of $\operatorname{tg} \delta$ in extremely low frequencies a) and at high frequencies b) of the composites with addition of $5 \%$ metallic powder

a

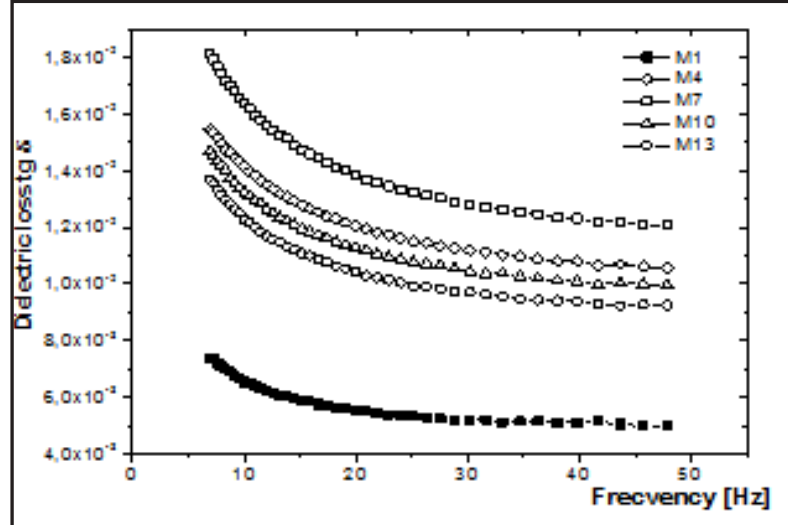

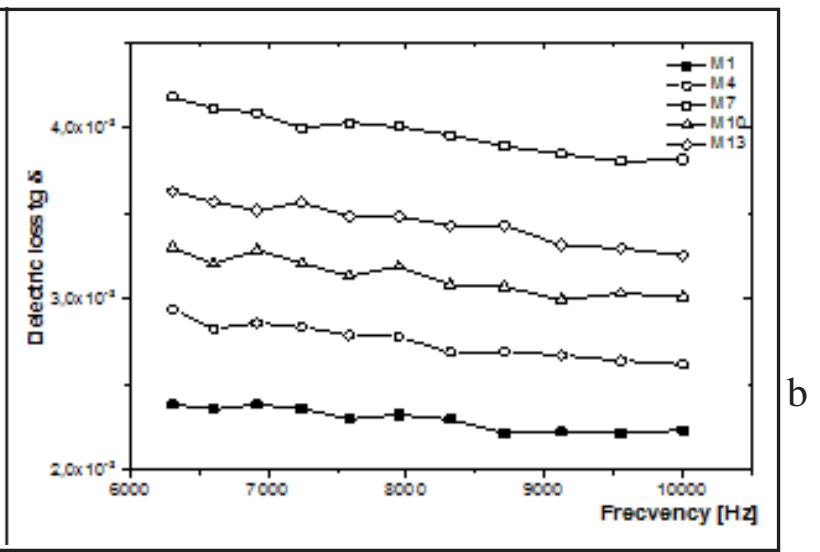

Fig. 16. Comparative evolutions of $\operatorname{tg} \delta$ in extremely low frequencies a) and at high frequencies b) of the composites with addition of $8 \%$ metallic powder the evolution of dielectric losses is almost the same as for HDPE with $5 \%$ metallic powder.

By comparative analysis of figures 14-16 one can see that the highest tg $\delta$ increases by the addition of Al $50 \mathrm{~nm}$ powders and the smallest increases by addition of Al 800 $\mathrm{nm}$ - suggesting that the increase in the powder specific surface area leads to increasing dielectric losses. The electrical conductivity values, $\sigma$, of the composites obtained at differentfrequencies, both ELF range and high frequency range are presented in table 5 .

Analyzing the values in table 5 it is found that in the ELF range (below $1 \mathrm{kHz}$ ) the electrical conductivity of the samples increases approximately linearly with the frequency (within the experimental errors limit).

The smallest growth slope, $\mathrm{k}$, ( $\mathrm{kMl}$ approximately $1.6 \mathrm{x}$ $10^{-12} \mathrm{~S} / \mathrm{m} / \mathrm{Hz}$ ) is recorded at the blank sample, pure HDPE and the highest slope at composite with $8 \%$ Al $50 \mathrm{~nm}$
( $\mathrm{kM7}$ about $2.6 \times 10^{-12} \mathrm{~S} / \mathrm{m} / \mathrm{Hz}$ ), the hierarchy being $\mathrm{kM1}$ $<\mathrm{kM} 2<\mathrm{kM} 3<\mathrm{kM} 4<\mathrm{kM} 8<\mathrm{kM} 11=\mathrm{kM} 9<\mathrm{kM} 5<\mathrm{kM} 10$ $<$ kM12 <kM13 <kM6 <M7.

It is also found that both at the aluminum powder and the iron powder, a smaller granulation leads to an increase in conductivity.

In the high frequencies range (greater than $5 \mathrm{kHz}$ ) the evolutions of $\sigma$ are almost linear, but with $\mathrm{k}^{\prime}$ slopes higher for the blank sample ( $\mathrm{k}^{\prime} \mathrm{M} 1$ of about $1.8 \times 10^{-12} \mathrm{~S} / \mathrm{m} / \mathrm{Hz}$ minimum value) and lower for samples with metallic filler $\left(2.26 \times 10^{-12} \mathrm{~S} / \mathrm{m} / \mathrm{Hz}\right.$ - maximum value) at the composite with $8 \%$ Fe $50 \mathrm{~nm}$ - the hierarchy being: $\mathrm{k}^{\prime} \mathrm{M} 1<\mathrm{k}^{\prime} \mathrm{M} 8<\mathrm{k}^{\prime} \mathrm{M} 2$ $<k^{\prime}$ M3 $<k^{\prime}$ M9 $<k^{\prime}$ M4 $=k^{\prime}$ M10 $<k^{\prime} M 11<k^{\prime}$ M5 $<k^{\prime}$ M6

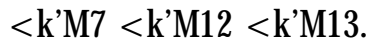

This behavior of slopes $k^{\prime}<k$ in the case of HDPE composites with metal powder filler, can be due to the film effect and the high frequency currents tendency to

Table 5

ELECTRICAL CONDUCTIVITY VALUES, $\sigma$, OF THE COMPOSITES OBTAINED AT DIFFERENT FREQUENCIES

\begin{tabular}{|c|c|c|c|c|c|c|c|c|c|c|}
\hline \multirow{2}{*}{\multicolumn{2}{|c|}{$\begin{array}{l}\text { Sample/ } \\
\text { powder }\end{array}$}} & \multirow{2}{*}{ code } & \multicolumn{8}{|c|}{ Electrical conductivity $\times 10^{-9}[\mathrm{~S} / \mathrm{m}]$} \\
\hline & & & $5 \mathrm{~Hz}$ & $50 \mathrm{~Hz}$ & $350 \mathrm{~Hz}$ & $1 \mathrm{kHz}$ & $6 \mathrm{kHz}$ & $10 \mathrm{kHz}$ & $50 \mathrm{kHz}$ & $100 \mathrm{kHz}$ \\
\hline \multicolumn{2}{|c|}{ pure HDPE } & M1 & 0.0226 & 0.185 & 0.903 & 1.61 & 6.2 & 9.53 & 86.1 & 180 \\
\hline \multirow{3}{*}{$\begin{array}{c}\mathrm{Al} \\
50 \mathrm{~nm}\end{array}$} & $3 \%$ & M5 & 0.0345 & 0.197 & 1.08 & 2.12 & 11.6 & 12.7 & 101 & 203 \\
\hline & $5 \%$ & M6 & 0.0406 & 0.227 & 1.24 & 2.48 & 12.1 & 14.8 & 110 & 219 \\
\hline & $8 \%$ & M7 & 0.0420 & 0.226 & 1.30 & 2.61 & 12.5 & 15.9 & 112 & 221 \\
\hline \multirow{3}{*}{$\begin{array}{c}\mathrm{Al} \\
800 \mathrm{~nm}\end{array}$} & $3 \%$ & $\mathrm{M} 2$ & 0.0249 & 0.153 & 0.951 & 1.72 & 9.05 & 10.1 & 96.8 & 189 \\
\hline & $5 \%$ & $\overline{\mathrm{MB}}$ & 0.0285 & 0.167 & 1.04 & 1.91 & 9.71 & 11.1 & 105 & 194 \\
\hline & $8 \%$ & M4 & 0.0314 & 0.182 & 1.06 & 1.97 & 9.72 & 11.4 & 106 & 198 \\
\hline \multirow{3}{*}{$\begin{array}{c}\mathrm{Fe} \\
50 \mathrm{~nm}\end{array}$} & $3 \%$ & M11 & 0.0294 & 0.189 & 1.10 & 2.11 & 11.7 & 12.3 & 99.8 & 201 \\
\hline & $5 \%$ & M12 & 0.0300 & 0.196 & 1.13 & 2.22 & 12.1 & 12.9 & 103 & 222 \\
\hline & $8 \%$ & $\mathrm{M} 13$ & 0.0330 & 0.231 & 1.14 & 2.26 & 12.2 & 13.4 & 104 & 229 \\
\hline \multirow{3}{*}{$\begin{array}{c}\mathrm{Fe} \\
790 \mathrm{~nm}\end{array}$} & $3 \%$ & M8 & 0.0325 & 0.179 & 1.03 & 2.09 & 11.3 & 12.5 & 97.8 & 185 \\
\hline & $5 \%$ & $\mathrm{Mg}$ & 0.0329 & 0.185 & 1.08 & 2.11 & 11.6 & 13.1 & 99.7 & 197 \\
\hline & $8 \%$ & M10 & 0.0339 & 0.191 & 1.09 & 2.19 & 11.7 & 13.2 & 101 & 198 \\
\hline
\end{tabular}


circulate on the surface and not in the conductor volume, which leads to a corresponding increase of the metal resistivity and the current frequency increase.

The increases in $\operatorname{tg} \delta$ and $\sigma$ of the composites investigated as compared to pure HDPE, clearly indicate that, the HDPE composites with metal powder achieved, have better electromagnetic shielding capability.

Taking into account the $\operatorname{tg} \delta$ and $\sigma$ frequency evolutions, it results that the composites obtained have a higher coefficient of attenuation in the extremely low frequencies range with many adverse effects on human health [50]).

\section{Conclusions}

For use in various applications such as semiconductor polymeric layers and / or electromagnetic shielding, the composites based HDPE nanostructured powder filler of alumina and iron have been characterized by comparative determinations of dielectric spectroscopy and SEM microscopy. SEM images have indicated that the pow ders used (especially those of $50 \mathrm{~nm}$ ) exhibit multiple agglomerations that are persistent, since they do not disintegrate during extrusion and injection processing.

Thermal analysis determinations have indicated that the HDPE used for the composite obtained can be processed (by extrusion and / or injection) without the risk of degradation by thermooxidation at temperatures between $149.11^{\circ} \mathrm{C}$ (end of the melting process) and $230.15^{\circ} \mathrm{C}$ (the beginning of the first thermooxidation process). Determinations by dielectric spectroscopy have demonstrated that the composite HDPE materials with metallic nanopowders filler have dielectric losses higher than pure HDPE (reference). The highest increases in $\operatorname{tg} \delta$, up to 2.6 times, were recorded for $50 \mathrm{~nm}$ nanopowders with a large specific surface area (over $20 \mathrm{~m}^{2} / \mathrm{g}$ ).

For the investigated samples the electrical conductivity increases (both in pure HDPE and in HDPE with metallic powder filler) at increasing frequency. As a result of the film effect, in the case of HDPE with metal filler, increases in the high frequency range are lower than in the extreme low frequency range.

Acknowledgment: This work was financially supported by the UEFISCDI of Romania, under the scientific Programme PN, Crt. No. $35 N / 2018$ and the POC project No 119/ 2016 cod SMIS 104089 ID P-37757.; contract 30PFE/2018 (between National $R \& D$ Institute for Electrical Engineering ICPE-CA and Romanian Ministry of Research and Innovation - $\mathrm{MCl}$ )

\section{References}

1. JINESCU, C.V., Mat Plast., 51, no. 3, 2014, p. 235.

2. JINESCU, C.V., Teodorescu, N., Mat. Plast., 52, no. 1, 2015, p. 1. 3. MIANDAD, R., BARAKAT, M.A., ABURIAZAIZA, A.S., REHAN, M., NIZAMI, A.S., Process Saf. Environ. Protect., 102, 2016, p. 822.

4. VOICU, R., Mat. Plast., 53, no.3, 2016, p. 465.

5. AL-SALEM, S.M., ANTELAVA, A., CONSTANTINOU, A., MANOS, G., DUTTA, A., 2017, Int. J. Environ. Manag., 197, 2017, p. 177.

6. TEODORESCU, N., STEFANESCU, M.F., PRODEA, I.M., Mat. Plast., 51, no. 4, 2014, p. 347.

7. DERMIBAS, A., J. Anal. Appl. Pyrolysis, 72, 2004, p. 97.

8. DESAl, S.B., GALAGE, C.K., Int. J. Eng. Res. Sci., 3, 2015, p. 590.

9. IANEZ-RODRIGUEZ, I., MARTÍN-LARA, M.A., BLAZQUEZ, G., PEREZ,

A., CALERO, M., Bioresour. Technol., 244, 2017, p. 741.

10. KUMARI, A., KUMAR, S., J. Anal. Appl. Pyrolysis., 124, 2017, p. 298.

11. MISKOLCZI, N., BARTHA, L., DEAK, G., JOVER, B., KALLO, D., J. Anal. Appl. Pyrolysis., 72, 2004, p. 235.

12.STERE, E.A., POPA, I., Electrotehnica, Electronica, Automatica (EEA), 66, no.3, 2018, p. 125.
13.LINGVAY, I., BORS, A.-M., LINGVAY, D., Electric Vehicles International Conference, EV 2017, p. 1.

14. ROGOZEA, E.A., MEGHEA, A., OLTEANU, N.L., BORS, A.M, MIHALY, M., Materials Letters, 151, no. 18661, 2015, p. 119.

15. BORS, A.M., MEGHEA, I., MIHALY, M., MUNTEANU, C., BADEA, M., International Multidisciplinary Scientific GeoConference Surveying Geology and Mining Ecology Management, SGEM, 1, no. 4, 2015, p. 533.

16.MEGHEA, I., BORS, A.M, MUNTEANU, C., International Multidisciplinary Scientific GeoConference Surveying Geology and Mining Ecology Management, SGEM, 2, no. 4, 2014, p. 351.

17. MEGHEA, I., BORS, A.G., MUNTEANU, G.-V., MUNTEANU, C., BORS, A.M, International Multidisciplinary Scientific GeoConference Surveying Geology and Mining Ecology Management, SGEM, 1, 2013, pp. 1113.

18. BORS, A.M., MEGHEA, I., NICOLESCU, A.M., BORS, A.G., 12th International Multidisciplinary Scientific GeoConference and EXPO Modern Management of Mine Producing, Geology and Environmental Protection, SGEM, 5, 2012, p. 891.

19. NEAMTU, C.S., STEFAN, S., BORS, A.-M., International J ournal of Environment and Waste Management, 5, no.1-2, 2010, p. 114.

20. NEAMTU, S., BORS, A.M., STEFAN, S., Rev. Chim. (Bucharest), 58, no.9, 2007. p. 938.

21. BORS, A.M., MEGHEA, A., NEAMTU, S., LESNIC, M., Rev. Chim. (Bucharest), 58, no. 8, 2007. p. 776.

22. BORS, A.M., CIUCULESCU, C.A., MEGHEA, A., Rev. Chim. (Bucharest), 58, no. 2, 2007. p. 151.

23. STEFAN, M., BORS, A.M, STEFAN, D.S., RADU, I.A.S., MARINESCU, C., Rev. Chim. (Bucharest), 68, no. 12, 2017, p. 2804.

24. LINGVAY, I., BORS, A.M., LINGVAY, D., BALACEANU, C.M., SZATMARI, I., MATEI, A.T., Electrotehnica, Electronica, Automatica (EEA), 65, no. 4, 2017, p. 5.

25. BORS, A.M., BUTOI, N., CARAMITU, A.R., MARINESCU, V., LINGVAY, I., Mat. Plast., 54, no. 3, 2017, p. 447.

26. AMMALA, A., BATEMAN, S., DEAN, K., PETINAKIS, E., SANGWAN, P., WONG, S., YUAN, Q., YU, L., COLIN P., LEONG, K.H., Progress in Polymer Science, 36, no. 8, 2011, p. 1015.

27. CARAMITU, A., BUTOI, N., RUS, T., LUCHIAN, A.-M., MITREA, S., Mat. Plast., 54 no. 2, 2017. p. 331.

28. VOINA, A., NIA, P., LUCHIAN, A.-M., BUTOI N., BORS, A.-M., LINGVAY, I., Electrotehnica, Electronica, Automatica (EEA), 65, no. 2, 2017, p. 60.

29. RUS, T., RADU, E., LINGVAY, I., LINGVAY, M., CIOBOTEA-BARBU, O.-C., CAMPUREANU, C., BENGA, F.-M., LAZAR, G.-C., VAIREANU, D.I., U.P.B. Sci. Bull., Series B, 79, no. 4, 2017. p. 167.

30. RADU, E., UDREA, O., MITREA, S., PATROI, D., LINGVAY, I., Electrotehnica, Electronica, Automatica (EEA), 63, no. 4, 2015, p. 84. 31. NOTINGHER, P.V., STANCU, C., ENESCU, I., ENESCU, A., Mat. Plast., 47, no. 4, 2010, p. 393.

32. NOTINGHER, P.V., STANCU, C., ENESCU, I., Mat. Plast., 48, no. 2, 2011, p. 171.

33. Ray, S.S., Okamoto, M., Progress in Polymer Science, 28, no. 11, 2003, p. 1539.

34. XU, R, MANIAS, E, SNYDER, A.J., RUNT, J., Macromolecules, 34, 2001, p. 337.

35. BHARADWAI, R.K., Macromolecules, 34, 2001, p. 1989.

36. BOURBIGOT, S., LEBRAS, M., DABROWSKI, F., GILMAN, J.W., KASHIWAGI, T., Fire Mater., 24, 2000, p. 201.

37. GILMAN, J.W., JACKSON, C.L., MORGAN, A.B., HARRIS, JR. R., MANIAS, E., GIANNELIS, E.P., WUTHENOW, M., HILTON, D., PHILLIPS, S.H., Chem. Mater., 12, 2000, p. 1866.

38. HAMCIUC, C., HAMCIUC, E., BACOSCA, I., OLARIU, M., Mat. Plast., 47, no. 1, 2010, p. 11.

39. KUSNEROVA, M., VALIEEK, J., HARNIEAROVA, M., HALUZIKOVA,

B., SKUBALA P., Mat. Plast., 51, no. 2, 2014, p.150.

40. SAVA, M., Mat. Plast., 53, no. 3, 2016, p. 473.

41. BUDASH, Y., NOVAK, D., PLAVAN, V., Mat. Plast., 53, no. 4, 2016, p. 693. 
42. NOVAC, O.C. MARIES, G.R.E., CHIRA, D., NOVAC, M., Mat. Plast., 54, no. 2, 2017, p. 274.

43. PROLONGO, S.G., BURON, M., GUDE, M.R., CHAOS-MORAN, R., CAMPO, M., URENA, A., Compos. Sci. Technol., 68, 2008, p. 2722. 44.***https://mol.hu/images/pdf/Vallalatiugyfeleknek/polimer termekek/hdpe-kozepes-esnagysurusegu_polietilenek/1100j_eng.pdf 45. ***https://nanografi.com/

46. VISAN, S., CIOBOTARU, V., IONESCU, F., BUDRUGEAC, P., GHIGA, C., Mat. Plast., 42, no. 3, 2005, p. 177.
47. LINGVAY, I., STANCU, C., BUDRUGEAC, P., CUCOS, A., LINGVAY, C., 7th International Symposium on Advanced Topics in Electrical Engineering, ATEE 2011, 5952210

48. LINGVAY, J., BUDRUGEAC, P., Korroz. Figy., 48, no. 3, 2008, p. 45. 49. LINGVAY, J., VELCIU, G., LINGVAY, D., BORS, A.-M., MOANTA A., Increasing Shielding Capabilities of Cement Mortars by Fly Ash Addition, Rev. Chim. (Bucharest), in press

50. LINGVAY, D., BORS, A.G., BORS, A.M., Electrotehnica, Electronica, Automatica (EEA), 66, no. 2, 2018, p. 5.

Manuscript received: 5.11 .2018 